\title{
Osteoblastoma in the retromolar region: a case report
}

\author{
Osteoblastoma em região retromolar: relato de caso
}

Jefferson da Rocha TENÓRIO'

Tiago João da SILVA FILHO'

Denise Hélen Imaculada Pereira de OLIVEIRA

Lélia Maria Guedes QUEIROZ1

\begin{abstract}
Osteoblastoma is a rare benign tumor that accounts for less than $1 \%$ of all bone tumors. About $10 \%$ of osteoblastomas are found in the skull bones and almost half of these cases involve the mandible, especially the posterior segments. This report describes the case of a 27-year-old female patient with a unilocular radiopaque expansive lesion in the left mandible, which had well-delimited margins and caused mild bone expansion. Microscopic analysis revealed the presence of mineralized material in the form of irregularly arranged vital trabeculae at different stages of mineralization. Osteocytes were trapped inside these trabeculae, which contained osteoclast-like multinucleated cells and voluminous pavement cells with hyperchromatic nuclei, sometimes interpreted as osteoblasts. Many bone-producing lesions have clinical, radiologic and histopathologic features that resemble osteoblastoma. The understanding and correlation of these findings are extremely important since they contribute to the correct diagnosis and appropriate treatment of this rare entity, improving its prognosis.
\end{abstract}

Indexing terms: Mandible. Mouth neoplasms. Osteoblastoma.

\section{RESUMO}

Osteoblastoma é um tumor benigno raro que representa menos de 1\% de todos os tumores ósseos e 10\% estão localizadas nos ossos do crânio e quase metade destes casos afeta a mandíbula, especialmente os segmentos posteriores. Este relato descreve um caso de uma lesão radiopaca unilocular expansiva na mandíbula esquerda, com margens bem delimitadas, causando expansão discreta do osso em um paciente do sexo feminino de 27 anos de idade. O exame microscópico revelou presença de material mineralizado na forma de trabéculas vitais com diferentes estágios de mineralização dispostas irregularmente e exibindo osteócitos aprisionados em seu interior, células multinucleadas semelhantes a osteoclastos e pavimentação células volumosas que têm núcleos hipercromáticos, por vezes interpretados como osteoblastos. Muitas lesões produtoras de osso possuem características clínicas, radiológicas ou histopatológicas semelhantes ao osteoblastoma. Compreender e correlacionar todos esses achados é de extrema importância, uma vez que auxilia no correto diagnóstico adequado tratamento desta entidade rara, levando a um bom prognóstico.

Termos de indexação: Mandíbula. Neoplasias bucais. Osteoblastoma.

\section{INTRODUCTION}

Osteoblastoma is a rare bone tumor that accounts for less than $1 \%$ of all maxillofacial tumors. This tumor is more common in young adults (mean age of 20 years) and mainly affects the spine, long bones, and metacarpal and metatarsal bones, in addition to facial bones including the jaws'.

Histologically, this tumor is characterized by the deposition of bone tissue at different stages of maturation and the abundant presence of osteoblasts, which are often intimately associated with bone neoformation. There are two main clinicopathologic subtypes of osteoblastoma: conventional osteoblastoma characterized by slow growth and well-defined sclerotic margins, which is fairly well vascularized and exhibits a mild inflammatory response, and the aggressive form characterized by a locally aggressive behavior and the propensity to recur. The latter exhibits histologic atypias that sometimes make it difficult to distinguish between this entity and low-grade osteosarcoma. Additionally, osteoblastomas can be classified according to the

\footnotetext{
${ }^{1}$ Universidade Federal do Rio Grande do Norte, Faculdade de Odontologia, Programa de Pós-Graduação em Patologia Oral. Av. Senador Salgado Filho, 1787, Lagoa Nova, 59056-000 Natal, RN, Brasil. Correspondência para / Correspondence to: DHIP OLIVEIRA. E-mail: <denisehelen2011@hotmail. com>.
} 
bone component involved as cortical, medullary or periosteal. The medullary and periosteal subtypes are more common in the jaw bones, while the cortical variant is frequently observed at extragnathic sites ${ }^{2-3}$.

In view of the broad spectrum of bone lesions with similar clinical, radiographic and histopathologic features described in the literature, these tumors have become a diagnostic challenge. A definitive diagnosis and appropriate treatment can only be established using the combination of clinical, histologic and radiographic components ${ }^{4}$. The objective of this study was to report the case of a young adult female patient with an osteoblastoma in the mandibular region.

\section{CASE REPORT}

A 27-year-old woman was seen at the OralMaxillofacial Surgery Service of the Department of Dentistry, Federal University of Rio Grande do Norte, with a bone lesion that was discovered on routine radiography. Clinical examination revealed mild expansion of cortical bone in the retromolar region. Tooth 38 was absent clinically and radiographically. The patient had no history of any surgical procedure in the affected area and reported no symptoms or systemic comorbidity. The imaging tests showed the presence of a well-circumscribed radiopaque lesion measuring approximately $2.5 \mathrm{~cm}$ in diameter, which was limited by a radiolucent halo in the region of tooth 38 (Figure 1)

An excisional biopsy was performed and the specimen was stored in 10\% formalin and sent for histopathologic analysis. The diagnostic hypotheses were ameloblastic fibro-odontoma, odontoma, and Pindborg tumor. Histopathological analysis demonstrated a bone lesion characterized by the presence of mineralized material in the form of irregular vital trabeculae at different stages of mineralization and osteocytes trapped inside these trabeculae. Osteoid material was sometimes observed interspersed in a fibrovascular stroma. The bone trabeculae exhibited a pavement of osteoblasts. Multinucleated cells, interpreted as osteoclasts, were also observed (Figure 2). These features led to the final diagnosis of osteoblastoma. The tumor was treated by excisional biopsy. The patient continues under clinicalradiographic follow-up and, so far, there have been no signs of recurrence of the tumor.

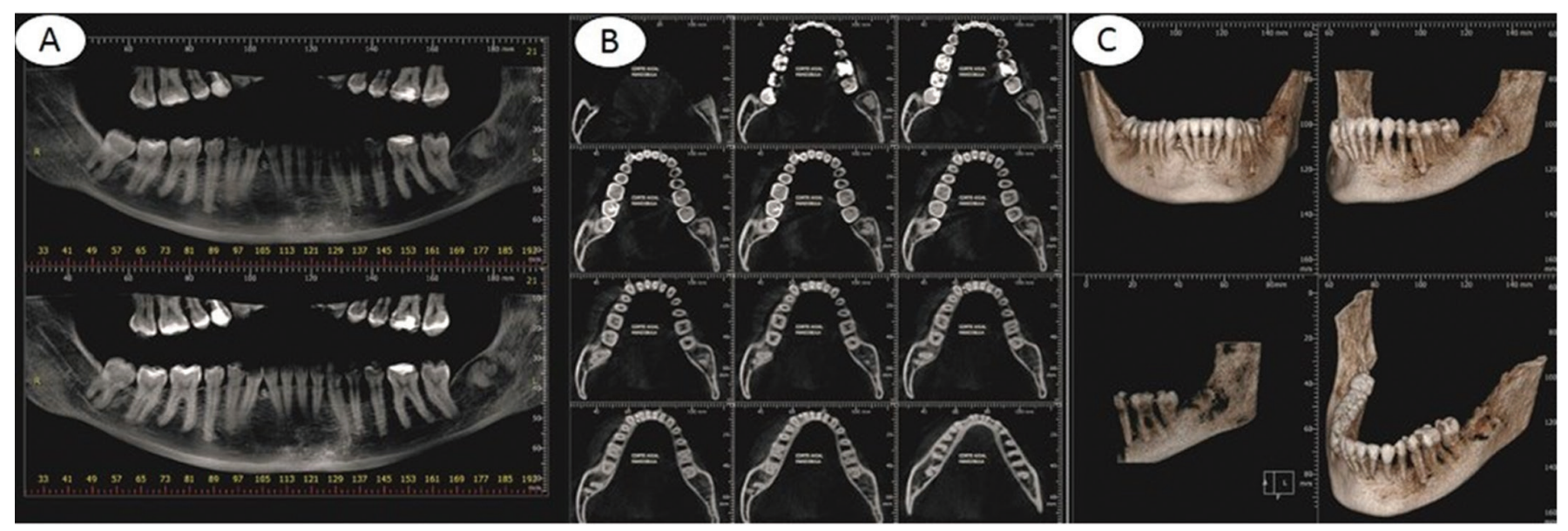

Figure 1. Computed tomography: (A) panoramic image; (B) axial sections; C) 3D reconstruction. 



Figure 2. Histopathologic features: (A) presence of mineralized material in the form of irregular vital trabeculae interspersed in a fibrovascular stroma; (B) osteocytes trapped in the bone matrix; (C) pavement of osteoblasts; (D) multinucleated giant cells compatible with osteoclasts. Panoramic Viewer 1.15.2 (3DHISTECH® Kft. 29-33, Konkoly-Thege M. str. Budapest, Hungary, H-1121).

\section{DISCUSSION}

Osteoblastoma is a rare benign bone tumor that has been recognized as a separate and distinct entity from osteoid osteoma. Although osteoblastoma is considered to have a benign biological behavior, the true nature of this tumor remains unclear ${ }^{4}$. Jaffe ${ }^{4}$ and Lichtenstein ${ }^{5}$ suggested osteoblastoma to be a true neoplasm of osteoblastic derivation. Other groups of researchers prefer to define this entity as the result of trauma or inflammation, as a local response to tissue damage, or even as a local alteration in bone physiology ${ }^{6}$.

Osteoblastoma has a slight predilection for females and affects patients within a wide age range, being most common in the $3^{\text {rd }}$ and $4^{\text {th }}$ decades of life. Involvement of the jaw bones is rare and, if present, most commonly occurs in the mandible ${ }^{3-4,7}$.
These findings agree with the present case, which was a female patient in the $3^{\text {rd }}$ decade of life with an osteoblastoma in the mandible.

Bone lesions exhibit a broad spectrum of clinical, radiographic and histopathologic features, a fact that makes the diagnosis of osteoblastoma difficult. The differential diagnosis of osteoblastoma includes other bone-producing lesions such as osteoid osteoma, osteosarcoma, cementoblastoma, and ossifying fibroma ${ }^{8}$. The histologic features of the present case, together with the clinical history and radiographic findings, were essential for the final diagnosis of osteoblastoma.

Osteoid osteoma differs from osteoblastoma by its smaller size $(<2 \mathrm{~cm})$. Many patients report local pain and radiography reveals evident sclerosis in peripheral areas. Histopathologically, osteoid osteoma forms narrower bone trabeculae with fewer osteoblasts and 
inconspicuous giant cells. The stroma is less vascularized when compared to osteoblastoma? ${ }^{9}$.

The aggressive type of osteoblastoma can exhibit significant cellular and architectural atypias such as the formation of even more irregular bone trabeculae, epithelioid-like osteoblasts sometimes scattered in the stroma, and prominent nucleoli. These findings obscure the final diagnosis and make the differentiation between osteoblastoma and low-grade osteosarcoma difficult ${ }^{8}$.

Osteoblastoma of the jaw bones is commonly treated by curettage or local surgical excision. En bloc resection is rarely performed. Radiotherapy has been described for cases in which surgical removal was not possible and when there is evidence of an aggressive behavior or multiple recurrences ${ }^{9-10}$. In the present case, excision biopsy was the definitive curative therapy.

In general, osteoblastoma has a good prognosis; however, a significant rate of recurrence has been reported in the literature, which is probably due to overly conservative therapies and incomplete excision of

\section{REFERENCES}

1. Caltabiano R, Serra A, Bonfiglio M, Platania N, Albanese V, Lanzafame $S$, et al. A rare location of benign osteoblastoma: case study and a review of the literature. Eur Rev Med Pharmacol Sci. 2012;16(13):1891-4.

2. Bokhari K, Hameed MS, Ajmal M, Togoo RA. Benign osteoblastoma involving maxilla: a case report and review of the literature. Case Rep Dent. 2012;2012:351241.

3. Kaur H, Verma S, Jawanda MK, Sharma A. Aggressive osteoblastoma of the mandible: a diagnostic dilemma. Dent Res J. 2012;9(3):334-7.

4. Jaffe HL. Benign osteoblastoma. Bull Hosp Joint Dis. 1956:17:141-51.

5. Lichtenstein L. Benign osteoblasma. A category of osteoid and bone forming tumors other than classical osteoid osteoma, which may be mistaken for giant cell tumor or osteogenic sarcoma. Cancer. 1956;9:1044-50.

6. Vinuth DP, Agarwal P, Gadewar D, Dube G, Dhirawni R. A large multifocal aggressive osteoblastoma of mandible: an the tumor. ${ }^{12}$ So far, the present patient shows no signs of recurrence and clinical-radiographic follow-up is still performed routinely.

\section{CONCLUSION}

Osteoblastoma is a rare benign bone tumor that is uncommon in the gnathic bones and its histological subtypes have different biological behaviors. Since osteoblastoma is a differentiated lesion, an early diagnosis is necessary and requires the careful correlation of clinical, radiographic and histopathologic features so that the correct treatment can be instituted.

\section{Collaborators}

JR TENÓRIO, TJ Silva Filho and DHIP OLIVEIRA were responsible for writing the article in all its phases. TJ Silva Filho: writing the article in all its phases. LMG QUEIROZ: Critical review relevant intellectual content; final approval of the version to be published.

immunohistochemistry case study report. J Dent Res Dent Clin Dent Prospects. 2014;8(1):51-5.

7. Mahajan A, Kumar P, Desai K, Kaul RP. Osteoblastoma in the retromolar region - Report of an unusual case and review of literature. J Maxillofac Oral Surg. 2013;12(3):338-40.

8. Harrington $\mathrm{C}$, Accurso BT, Kalmar JR, Iwenofu OH, Agrawal $A$, Allen CM, et al. Aggressive osteoblastoma of the maxilla: a case report and review of the literature. Head Neck Pathol. 2011;5(2):165-70.

9. Woźniak AW, Nowaczyk MT, Osmola K, Golusinski W. Malignant transformation of an osteoblastoma of the mandible: case report and review of the literature. Eur Arch Otorhinolaryngol. 2010;267(6):845-9.

10. Shah S, Kim JE, Huh KH, Yi WJ, Heo MS, Lee SS. Recurrent osteoblastoma of the maxilla. Dentomaxillofac Radiol. 2013;42(5):20100263. 